\title{
Profil Kemampuan Siswa Peserta Olimpiade Matematika Dalam Menjawab Soal Pilihan Ganda
}

\author{
Sanapiah $^{1}$, Ade Kurniawan ${ }^{2}$, \& Yuntawati \\ ${ }_{1,2, \& 3}$ FSTT Universitas Pendidikan Mandalika, Mataram-NTB \\ Email: sanapiah@ikipmataram.ac.id
}

\begin{abstract}
This study aims to describe the ability profile of the Mathematical Olympiad participants at the Regency / City level in NTB Province in answering multiple choice questions. Research subjects with this qualitative approach numbered 68 people representing 6 Regencies / Cities in NTB Province from the Math Olympiad competition consisting of 25 people from Mataram City, 15 people from West Lombok Regency, 3 people from Central Lombok Regency, 23 people from Regency East Lombok, and 2 people from Sumbawa Besar Regency. From 68 participants who registered in the Mathematical Olympiad, 33 men and 35 women were known, consisting of 40 people from the junior high school level and 28 people from the MTs level. The multiple choice questions analyzed consisted of 60 question items, if the answer was correct (B) given a score of +2 , if the answer (S) was given a score of -1, and if not answered / blank (K) was given a score of 0 . The results of this study found 3 ability profiles possessed by olympic participant students in answering multiple choice questions namely 1) students are said to have high ability, if more than $50 \%$ of the total number of questions can be answered correctly by students compared to incorrect or unanswered answers, 1) students are said to have the ability is, if the percentage of the number of questions that can be answered is proportional to the number of correct answers to the number of incorrect or unanswered answers, 3) students are said to have high ability, if more than $50 \%$ of the total number of questions answered incorrectly by students compared to correct answers or not answered.
\end{abstract}

Keywords: Student Profile, Math Olympiad, Multiple choice questions

\begin{abstract}
Abstrak: Penelitian ini bertujuan untuk mendeskripsikan profil kemampuan yang dimiliki oleh para peserta olimpiade matematika tingkat Kabupaten/Kota di Propinsi NTB dalam menjawab soal pilihan ganda. Subjek penelitian dengan pendekatan kualitatif ini berjumlah 68 orang yang mewakili 6 Kabupaten/Kota di Propinsi NTB dari ajang kompetisi olimpiade matematika yang terdiri dari 25 orang dari Kota Mataram, 15 orang dari Kabupaten Lombok Barat, 3 orang dari Kabupaten Lombok Tengah, 23 orang dari Kabupaten Lombok Timur, dan 2 orang dari Kabupaten Sumbawa Besar. Dari 68 peserta pendaftar olimpiade matematika ini, diketahui 33 orang laki-laki dan 35 perempuan yang terdiri dari 40 orang dari jenjang SMP dan 28 orang dari jenjang MTs. Soal pilihan ganda yang dianalisis terdiri dari 60 item pertanyaan, jika menjawab benar (B) diberikan skor +2 , jika menjawab (S) diberikan skor -1 , dan jika tidak menjawab/kosong (K) diberikan skor 0 . Hasil dari penelitian ini menemukan 3 profil kemampuan yang dimiliki siswa peserta olimpiade dalam menjawab soal pilihan ganda yaitu 1) siswa dikatakan memiliki kemampuan tinggi, jika lebih dari $50 \%$ dari jumlah soal dapat dijawab dengan benar oleh siswa dibandingkan dengan jawaban salah atau tidak dijawab, 1) siswa dikatakan memiliki kemampuan sedang, jika persentase dari jumlah soal yang dapat dijawab sebanding antara jumlah jawab soal benar dengan jumlah jawaban salah atau tidak dijawab, 3) siswa dikatakan memiliki kemampuan tinggi, jika lebih dari 50\% dari jumlah soal dijawab dengan salah oleh siswa dibandingkan dengan jawaban benar atau tidak dijawab.
\end{abstract}

Kata kunci: Profil Kemampuan siswa, Olimpiade Matematika, Soal pilihan ganda

\section{PENDAHULUAN}

Olimpiade merupakan salah satu perlombaan internasional yang dihadiri oleh hampir semua negara di dunia (Regia, 2019). Awal mula olimpiade berlangsung pada masa kerajaan Yunani kuno yang lebih dikenal sebagai olimpiade kuno (Shaw, 2002). Pertandingan 
olimpiade kuno pada masa itu diselenggarakan sebagai ajang festival keagamaan dan atletik yang diadakan setiap empat tahun di tempat suci Zeus di Olympia, Yunani. Pada tahun 1896, olimpiade kuno ditinggalkan dan berkembang menjadi olimpiade modern yang pertama diselenggarakn di Athena, Yunani. Sejak saat itu, pertandangan Olimpiade dijadikan sebagai ajang kompetisi olahraga terbesar dan terkemuka di dunia yang di diselenggarakan tiap empat tahun sekali pada musim panas dan musim dingin di negara yang berbeda yang di tetapkan oleh Komite Olimpiade Internasional (IOC). Sedangkan indonesia, pertama kali terlibat dalam kompetisi internasional ini pada tahun 1952 di Finlandia yang hanya mengirimkan 3 orang artletnya.

Seiring dengan perjalanan waktu, olimpiade tidak hanya sebagai ajang kompetisi dalam bidang olahraga saja. Namun olimpiade juga berkembang baik dalam skala internasional maupun nasional di bidang ilmu pengetahuan, diantaranya International Mathematical Olympiad (IMO) dan International Physics Olympiad(IPhO). International Mathematical Olympiad atau Olimpiade Matematika Internasional (OMI) pertama kali diselenggarakan pada tahun 1959 di Rumania yang diikuti oleh 40 peserta dari 7 negara (Lee-Chua, 2016), International Physics Olympiad atau Olimpiade Fisika Internasional (OFI) diadakan di Warsawa, Polandia pada tahun 1967 (Gorzkowski, 2007). Sedangkan olimpiade dalam skala nasional indonesia disebut dengan Olimpiade Sains Nasional (OSN) yang pertama kali diselenggarakan di Yogyakarta pada tahun 2002.

Di Indonesi, ajang kompetisi OSN merupakan salah satu ajang kompetisi tahunan yang dimaksudkan untuk meningkatkan kemampuan kompetitif bagi para siswa untuk bersaing secara sehat dalam penguasaan ilmu pengetahuan teknologi sekaligus meningkatkan kemampuan siswa di bidang matematika dan IPA (Mairing, dkk. 2013;). Para peserta OSN yang terpilih untuk mengikuti kompetisi nasional ini sudah dipastikan telah melewati tahan seleksi yang ketat dimulai dari seleksi tingkat Sekolah, tingkat kabupaten/kota, dan tingkat propinsi (Yaqutunnafis, 2020; Suhendar dkk, 2020). Peserta-peserta OSN terbaik tingkat kabupaten/kota biasanya dipilih atau direkomendasi oleh guru-guru mata pelajaran yang mewakili dari kelas masing-masing.

Materi uji yang disajikan dalam soal OSN matematika jenjang SMP/MTs tidak terlepas dari 3 materi utama matematika yaitu tentang materi bilangan dan akan dilanjutkan dengan materi lain seperti, Aljabar, Geometri. Namun di beberapa kegiatan olimpiade yang diselenggarakan, konsep konsep matematika yang menjadi materi dalam soal-soal olimpiade matematika yaitu bilangan, aljabar, geometri, statistika dan peluang (Prasetya \& Widodo, 2012; Suryawan dkk, 2017). Materi olimpiade pada dasarnya bersumber pada kurikulum yang berlaku untuk mata pelajaran matematika, buku buku pelajaran, buku-buku penunjang dan bahan lain 
yang relevan. Materi yang diujikan adalah soal-soal eksplorasi, penalaran, kreatifitas serta pemahaman konsep melalui penggunaan alat peraga (Latifah dkk, 2018; Suhendar dkk, 2020;). Para siswa-siswa peserta OSN baik tingkat Kabupaten/Kota, Propinsi maupun Nasional, bahkan Internasional siswa dituntut untuk menggunakan seluruh kemampuan matematika yang telah diperoleh di sekolah secara kreatif untuk menyelesaikan soal-soal matematika yang membutuhkan penalaran tingkat tinggi.

Keberhasilan siswa dalam menyelesaikan soal-soal OSN tergantung dari kreatifitas dan inovasi mereka dalam memahamai, menerjemahkan dan merencanakan pemecahan soalsoal/masalah-masalah. Namun untuk soal-soal yang disajikan dalam setiap kompetisi olimpiade yang diselenggarakan oleh lembaga atau instansi pendidikan terkait, biasanya soal yang buat sangat beragama. Diantaranya ada soal yang berbentuk soal benar-salah, pilihan ganda (multiple Choice), dan isian (Completion). Khusus utntuk menjawab soal pilihan ganda, siswa peserta olimpiade harus teliti dan cermat dalam menjawab dan menentukan pilihan. Karena dalam soal olimpiade seperti ini ada jawaban yang hampir sama yang kadang sulit dibedakan jika salah dalam menentukan penyelesaian, namun hanya terdiri dari satu jawaban dan jawaban yang lain sebagai pengecohnya (Arikunto, 2012). Artinya dalam penyusunan soal pilihan ganda, harus memperhatikan kaidah yang sudah ditetapkan (Winata dkk 2014).

Keberadaan program OSN yang terus diselenggarakn oleh pemerintah bertujuan untuk membentuk watak dan karakter siswa agar menyenangi dan menguasai sains. Namun di lain pihak, tidak semua sekolah melirik pentingnya OSN bagi siswa-siswanya. Hal ini mengakibatkan sekolah tidak segera berbedah dalam menyiapkan fasilitas-fasilatas yang mendukung untuk melakukan pembinaan khusus bagi siswa-siswa berprestasinya. Sebagaimana yang diungkapkan oleh (Tohir, 2019) bahwa (1) kegiatan pembinaan olimpiade matematika belum berjalan secara efesien dan efektif di sekolah masing-masing, (2) para guru masih kesulitan dalam memahami soal-soal olimpiade matematika, (3) para guru minim pengalaman dalam membina kegiatan olimpiade matematika, dan (4) belum adanya bahan ajar olimpiade matematika yang cocok bagi para siswa.

Oleh karena itu, IKIP Mataram sebagai salah satu kampus LPTK yang mencetak para calon pendidik di wilayah NTB, memberikan wadah untuk kompetisi matematika dengan menyelenggarakan kegiatan olimpiade tingkat kabupaten/Kota. Kegiatan ini akan menjadi langkah awal bagi para siswa SMP dan SMA yang memiliki potensi dan kemampuan yang memadai untuk mengikuti kegiatan olimpiade pada tingkat propinsi,. Selain itu, Kegiatan ini memberikan kesempatan dan pengalaman bagi para siswa untuk terlibat langsung dalam kompetisi olimpiade tingkat kabupaten/Kota. Tidak sebatas itu, para guru akan dapat pengalaman langsung dalam membina siswa-siswanya untuk ikut serta berperan aktif dalam 
pembinaan selanjutnya. Hasil dari kegiatan olimpiade ini nantinya dapat menjadi tolak ukur untuk mengetahui kemampuan dan potensi yang di miliki oleh masing-masing siswa untuk dapat mengikuti dan mengembangkan potensinya menuju tahap seleksi OSN ke tingkat propinsi.

Berdasarkan uraian diatas, maka dianggap perlu untuk mengidentifikasi kemampuan yang dimiliki oleh para peserta olimpiade yang mewakili sekolahnya masing-masing dalam menyelesaikan setiap soal yang diberikan dalam kompetensi olimpiade matematika ini. Penyelesaian soal yang dimaksud adalah menjawab soal pilihan ganda dengan baik dan cermat sesuai pengalaman siswa. Selain itu, perlu juga diidentifikasi profil setiap siswa peserta olimpiade dengan cara mengumpulkan data jenjang sekolah dan kabupaten yang mewakilinya. Hasil dari analisis kemampuan pemahaman para peserta nanti dapat memberikan konstribusi untuk pembinaan lebih lanjut oleh para guru pendamping.Hasil dari penelitian ini dapat memberikan gambaran secara umum tentang pemahaman para siswa olimpiade matematika tingkat kabupaten/kota dalam menjawab menyeselaikan soal pilihan ganda, seperti bagaimana siswa memahami informasi yang terdapat pada soal, kecermatan dalam menyusun startegi, kemahiran dalam menggunakan startegi yang dipilih, keterampilan dalam menguraikan jawaban, penguasaan terhadap materi olimpiade matematika, dan kecenderungan dalam mengandalkan hafalan atau tiruan berdasarkan solusi penyelesaian yang sudah ada atau sudah pernah dibahas sebelumnya (Tohir, 2019).

\section{METODE}

Penelitian ini merupakan penelitian deskriptif kualitatif yang bertujuan untuk mendeskripsikan profil kemampuan yang dimiliki oleh para peserta olimpiade matematika tingkat kabupaten NTB dalam menjawab soal pilihan ganda. Soal pilihan ganda yang diberikan terdiri dari 60 item pertanyaan dengan tingkat kesulitan soal bervariasi (mudah, sedang, dan sulit). Soal-soal pilihan ganda dikembangkan atau diambil dari soal-soal olimpiade tingkat nasional dan internasional yang sudah pernah di ujikan.

Analisis hasil penelitian ini hanya terbatas pada pengolahan data jawaban benar, salah, dan kosong. Adapun ketentuan pemberian skor pada jawaban soal pilihan ganda antara lain, jika menjawab benar (B) diberikan skor +2 , jika menjawab (S) diberikan skor -1 , dan jika tidak menjawab/kosong $(\mathrm{K})$ diberikan skor 0 .

Data subjek penelitian ini diperoleh dari data pendaftar olimpiade matematika antar Kabupaten dan Kota di NTB yang diselenggarakan oleh Fakultas Pendidikan Matematika dan IPA IKIP Mataram tahun 2018 pada tingkat SMP/MTs. Terdapat 68 orang pendaftar dari 6 
Kabupaten dan Kota di NTB yang terdiri dari 25 orang Kota Mataram, 15 orang dari Kabupaten Lombok Barat, 3 orang dari Kabupaten Lombok Tengah, 23 orang dari Kabupaten Lombok Timur, dan 2 orang dari Kabupaten Sumbawa Besar. Dari 68 peserta pendaftar olimpiade matematika ini, diketahui 33 orang laki-laki dan 35 perempuan yang terdiri dari 40 orang dari jenjang SMP dan 28 orang dari jenjang MTs baik Negeri maupun Swasta.

\section{HASIL DAN PEMBAHASAN}

Dalam analisis hasil penelitian ini, hanya akan dideskripsikan 3 persoalan utama berdasarkan hasil temuan, antara lain 1) Deskripsi tentang jumlah siswa yang menjawab soal dengan benar, salah dan tidak menjawab/kosong, 2) Deskripsi kemampuan siswa yang menjawab soal dengan benar yang masuk dalam kategori kemampuan tinggi, dan 3) Deskripsi kemampuan siswa dalam menjawab soal pilihan ganda berdasarkan jenjang sekolah, yang akan diurakan sebagai berikut:

\section{1) Deskripsi tentang jumlah siswa yang menjawab soal dengan benar, salah dan tidak menjawab/kosong.}

Dari hasil temuan dalam penelitian ini, kemampuan siswa dalam menjawab soal dengan benar, salah dan tidak menjawab/kosong dari 60 soal pilihan ganda dikelompokkan ke dalam 3 kategori yaitu rendah, sedang dan tinggi. Kategori jumlah siswa dalam menjawab soal dengan benar disajikan pada table 1.1 berikut:

Tabel 1. Jumlah siswa dalam menjawab soal dengan benar

\begin{tabular}{cccc}
\hline No. & Kategori Kemampuan siswa & Interval jumlah soal benar & Jumlah \\
\hline $\mathbf{1}$ & Rendah & $0-20$ & 28 \\
$\mathbf{2}$ & Sedang & $21-40$ & 34 \\
$\mathbf{3}$ & Tinggi & $41-60$ & 6 \\
\hline
\end{tabular}

Tabel 1 memberikan gambaran tentang kemampuan siswa dalam menjawab soal dengan benar. Data tersebut menunjukkan bahwa terdapat 28 siswa menjawab dengan benar yang kurang dari 21 soal, terdapat 34 siswa menjawab dengan benar dengan jumlah soal antara 20-41, dan hanya 6 orang yang mampu menjawab lebih dari 40 soal dengan benar. Namun dari hasil temuan data ini diperoleh bahwa jumlah soal terbanyak yang berhasil dijawab dengan benar dari 60 soal hanya 45 soal dan jumlah soal yang paling sedikit dijawab dengan benar ada 7 soal.

Berdasarkan temuan ini, peneliti menduga bahwa peserta olimpiade yang mengikuti kompetisi ini dipilih hanya melihat dari kemampuan prestasi dikelasnya. Namun belum masuk dalam kategori siswa yang mendapatkan pembinaan khusus OSN di sekolahnya. Siswa-siswa yang diikutkan dalam olimpidae seharusnya adalah siswa-siswa yang mempunyai bakat dan 
minat yang tinggi dalam belajar. Oleh karena itu, sekolah perlu memilih calon-calon siswa prestasi untuk dibina secara berjenjang. Keputusan yang harus diambil ini oleh pihak sekolah dalam memilih calon peserta olimpiade diharapkan tidak obyektif, tidak memihak, serta transparan agar kualitas SDM yang diperoleh dapat sesuai dengan harapan (Situmorang, 2016).

Untuk kategori jumlah siswa dalam menjawab soal dengan salah juga dikelompokkan dalam tiga kategori, yang disajikan pada tabel 2 berikut:

Tabel 2. Jumlah siswa dalam menjawab soal dengan salah

\begin{tabular}{cccc}
\hline No. & Kategori Kemampuan siswa & Interval jumlah soal jawab salah & Jumlah \\
\hline $\mathbf{1}$ & Tinggi & $0-20$ & 37 \\
$\mathbf{2}$ & Sedang & $21-40$ & 24 \\
$\mathbf{3}$ & Rendah & $41-60$ & 7 \\
\hline
\end{tabular}

Tabel 2 memberikan deskripsi tentang jumlah siswa dalam menjawab soal dengan salah. Data tersebut memberikan informasi bahwa terdapat 7 siswa yang memiliki kemampuan sangat rendah, karena menjawab soal dengan salah lebih dari 40 soal. Hal ini memberikan gambaran bahwa 7 anak tersebut memiliki kemampuan yang dibawah rata-rata kemampuan peserta olimpiade matematika lainnya. Sedangkan yang menjawab soal dengan salah kurang dari 21 soal sebanyak 37 siswa yang dikategorikan sebagai siswa berkategori kemampuan tinggi. Dari hasil temuan data ini diperoleh bahwa jumlah soal terbanyak yang dijawab dengan salah adalah 50 soal dan jumlah soal yang paling sedikit dijawab salah ada 2 soal.

Gambaran dari 7 siswa peserta olimpiade yg memiliki hasil paling rendah menunjukkan bahwa siswa-siswa tersebut lebih memilih/menjawab soal dengan cara menduga-duga pilihan jawaban tanpa memiliki kemampuan yang memadai ketika berhadapan dengan soal olimpiade. Soal olimpide yang di ujikan memang memiliki level kesulitan yang sangat beragam walaupun dalam bentuk soal pilihan ganda. Oleh karena itu, siswa peserta olimpiade harus mendapatkan pembinaan khusus untuk dapat ikut/tampil dalam kompetisi ini baik pada tingkat kabupaten, nasional maupun internasional.

Namun jika data ini dihubungkan antara jumlah maksimum dan minimum soal yang dijawab benar, salah dan tidak menjawab, maka diperoleh gambaran seperti yang di sajikan dalam table 3 berikut:

Tabel 3. Jumlah maksimum dan minimum soal yang dijawab benar, salah, dan tidak menjawab/kosong

\begin{tabular}{cccc}
\hline No. & Jawaban soal pilihan ganda & Maksimum & Minimum \\
\hline $\mathbf{1}$ & Benar & 45 & 7 \\
$\mathbf{2}$ & Salah & 50 & 2 \\
$\mathbf{3}$ & Tidak menjawab/kosong & 42 & 0 \\
\hline
\end{tabular}


Tabel 3 memberikan gambaran bahwa banyak soal yang di jawab salah oleh siswa peserta olimpiade matematika lebih besar di bandingkan dengan jumlah soal yang di jawab benar. Namun di sisi lain, jumlah siswa yang menjawab benar lebih banyak 3 soal dari jumlah siswa yang tidak menjawab. Hasil ini memberikan deskripsi bahwa soal-soal yang diberikan dalam kompetisi olimpiade ini adalah soal-soal yang harus diselesaikan oleh siswa-siswa yang memang memiliki kemampuan tingkat tinggi atau memiliki daya nalar yang cukup baik.

\section{2) Deskripsi kemampuan siswa yang menjawab soal dengan benar yang masuk dalam kategori kemampuan tinggi}

Jika merujuk kembali pada tabel 1 diatas. Data tersebut memberikan gambaran bawah hanya ada 6 orang masuk dalam kategori memiliki kemampuan tinggi yang bisa masuk ke tahap pembinaan lebih lanjut untuk mengikuti seleksi calon peserta OSN tingkat propinsi. Adapun gambaran perolehan nilai berdasarkan skornya di peroleh keenam orang yang memiliki kemampuan tinggi dalam kompetisi olimpiade ini disajikan pada table 4 sebagai berikut:

Tabel 4. Data nilai akhir OSN Tingkat Kabupaten/Kota keenam siswa dalam ketegori kemampuan tinggi

\begin{tabular}{ccccccc}
\hline No. & $\begin{array}{c}\text { Jenjang } \\
\text { Sekolah }\end{array}$ & $\begin{array}{c}\text { Jumlah } \\
\text { Jawaban } \\
\text { Benar }\end{array}$ & $\begin{array}{c}\text { Jumlah } \\
\text { Jawaban } \\
\text { Salah }\end{array}$ & $\begin{array}{c}\text { Jumlah Tidak } \\
\text { menjawab/kosong }\end{array}$ & Nilai & Peringkat \\
\hline 1. & MTs & 41 & 6 & 13 & 76 & II \\
2. & MTs & 41 & 12 & 7 & 70 & V \\
3. & SMP & 45 & 13 & 2 & 77 & I \\
4. & SMP & 44 & 11 & 3 & 72 & IV \\
5. & SMP & 43 & 14 & 8 & 74 & III \\
\hline 6. & SMP & 42 & 10 & 5 & \\
\hline
\end{tabular}

Tabel 4 memberikan gambaran bahwa siswa yang memiliki skor jawaban benar belum tentu mendapatkan hasil akhir yang yang lebih tinggi dibandingkan dengan siswa yang memiliki jawab benar lebih sedikit. Namun yang perlu diperhatikan adalah jumlah jawaban salah yang dilakukan akan sangat mempengaruhi penentuan nilai akhir. Salah satunya, jika diperhatikan pada jumlah jawaban siswa pada urutan no. 4. Siswa tersebut memiliki 43 jawaban benar, tapi pada nilai akhir dia hanya mendapatkan nilai 72 lebih rendah dibandingkan dengan siswa pada urutan 1 dan 4 yang jumlah jawaban benarnya lebih sedikit. Namun nilai akhir yang diperoleh lebih tinggi yaitu secara berturut-turut 76 dan 74 .

3) Deskripsi kemampuan siswa dalam menjawab soal pilihan ganda berdasarkan jenjang sekolah 
Berdasarkan jumlah siswa jenjang sekolah menengah, peserta kompetisi olimpiade tingkat kabupaten/kota ini diikuti oleh 40 siswa dari jenjang SMP dan 28 siswa dari jenjang MTs baik negeri maupun swasta. Berdasarkan data penelitian ini, siswa-siswa dari jenjang SMP maupun MTs memiliki kemampuan menjawab soal olimpiade dalam bentuk soal pilihan ganda ini yang hampir sama. Jika dilihat berdasarkan tabel 4, terdapat 2 orang siswa masuk dalam kategori memiliki kemampuan tinggi dengan urutan peringkat 2 dan 5 dari 6 orang terbaik dalam kompetensi ini. Hal ini menegaskan bahwa sekolah-sekolah yang mengirimkan siswa dalam ajang kompetensi ini baik MTs maupun SMP adalah sekolah-sekolah yang ingin menumbuh kembangkan kemampuan peserta didiknya untuk dapat mengusai sains secara mendalam.

\section{SIMPULAN DAN SARAN}

Berdasarkan hasil penelitian ini, dapat disimpulankan bawa terdapat 3 profil kemampuan yang dimiliki siswa peserta olimpiade dalam menjawab soal pilihan ganda yaitu 1) siswa dikatakan memiliki kemampuan tinggi, jika lebih dari 50\% dari jumlah soal dapat dijawab dengan benar oleh siswa dibandingkan dengan jawaban salah atau tidak dijawab, 1) siswa dikatakan memiliki kemampuan sedang, jika persentase dari jumlah soal yang dapat dijawab sebanding antara jumlah jawab soal benar dengan jumlah jawaban salah atau tidak dijawab, 3) siswa dikatakan memiliki kemampuan tinggi, jika lebih dari $50 \%$ dari jumlah soal dijawab dengan salah oleh siswa dibandingkan dengan jawaban benar atau tidak dijawab.

\section{DAFTAR PUSTAKA}

Arikunto, S. (2012). Dasar-Dasar Evaluasi Pendidikan. Jakarta: Bumi Aksara.

Azizah, R. (2019). Profil Peserta Olimpiade Matematika dalam Konstruksi Soal Cerita. Jurnal Tadris Matematika, 2(1), 71-84.

Gorzkowski, W. (2007). International Physics Olympiads (IPhO): their history, structure and future. AAPPS Bulletin, 17(3).

Latifah, I. W., Susanto, S., Sugiarti, T., Fatahillah, A., \& Murtikusuma, R. P. (2018). Profil Berpikir Siswa Peserta Olimpiade Matematika dalam Menyelesaikan Masalah Aljabar. KadikmA, 9(2), 145-154.

Lee-Chua, Q. N (2016). Going for Gold in the International Math Olympiad. Philippine Journal of Science, 145 (4): vii-xii, December 2016 ISSN 0031-7683.

Mairing, J. P., Budayasa, I. K., \& Juniati, D. (2013). Perbedaan profil pemecahan masalah peraih medali OSN matematika berdasarkan jenis kelamin. Jurnal Ilmu Pendidikan, 18(2).

Prasetya, A., \& Widodo, A. T. (2012). Model Ideal Problem Solving untuk Pencapaian Kemampuan Pemecahan Masalah di Kelas Olimpiade. Lembaran Ilmu Kependidikan, 41(1).

Tohir, M. (2019). Modul Pembinaan Olimpiade Guru MGMP Matematika SMP Kabupaten Madiun.

Regia, S. R. (2019). Upaya International Olympic Committee (IOC) dalam meningkatkan kesetaraan gender di Olimpiade pada tahun 2008-2016. 
Rohim, M. F., \& Sari, A. F. (2019). Keterampilan Siswa Memecahkan Masalah Olimpiade Matematika Ditinjau dari Kepribadian Tipe Senising dan Intuiting. Jurnal Elemen, 5(1), 80-92.

Shaw, P. J. (2002). Discrepancies in Olympiad dating and chronological problems of archaic Peloponnesian history (No. 166). Franz Steiner Verlag.

Situmorang, h. (2016). Sistem Pendukung Keputusan Pemilihan Calon Peserta Olimpiade Sains Tingkat Kabupaten Langkat Pada Madrasah Aliyah Negeri (Man) 2 Tanjung Pura Denganmenggunakan Metode Simple Additive Weighting (SAW). Jurnal times, 4(2), 24-30.

Suhendar, U., Ekayanti, A., \& Merona, S. P. (2020). Pola Pembinaan Olimpiade Sains Nasional Matematika SMP di Kabupaten Ponorogo. Mosharafa: Jurnal Pendidikan Matematika, 9(2), 179-190.

Suryawan, I. P. P., Gita, I. N., \& Hartawan, I. Y. (2017). Pengayaan Materi dan Pelatihan Penyelesaian Soal-Soal Olimpiade Matematika bagi Siswa Berbakat SD N 3 Sambangan. WIDYA LAKSANA, 6(2), 100-112.

Winata, N. P. S., Putrayasa, I. B., \& Sudiara, I. N. S. (2014). Analisis Butir Soal Pilihan Ganda Mata Pelajaran Bahasa Indonesia SMK Negeri 3 Singaraja. Jurnal Pendidikan Bahasa Dan Sastra Indonesia Undiksha, 2(1).

Yaqutunnafis, L. (2020). Manajemen kelas Olimpiade Sains Nasional (OSN) di MTs Negeri 1 Kota Mataram. Media bina ilmiah, 14(10), 3281-3290. 